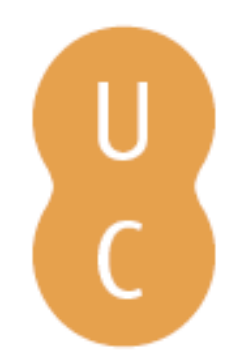

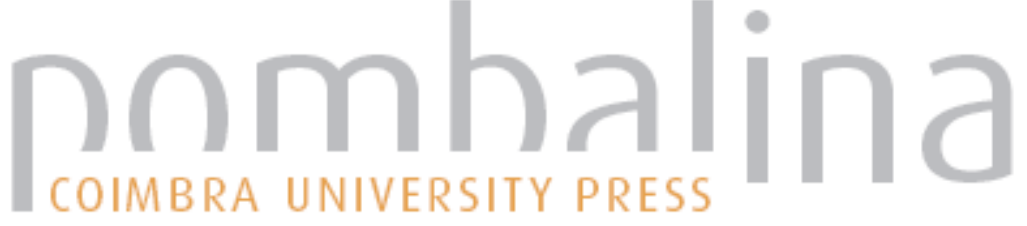

\section{Braila: onde o Danúbio vem à cidade}

Autor(es): $\quad$ Lascu, Nicolae, ed. lit.; China, Andreea Mirela

Publicado por: Imprensa da Universidade de Coimbra

URL

persistente:

URI:http://hdl.handle.net/10316.2/39325

DOI:

DOI:http://dx.doi.org/10.14195/978-989-26-1025-2_10

Accessed : $\quad$ 26-Apr-2023 02:07:30

A navegação consulta e descarregamento dos títulos inseridos nas Bibliotecas Digitais UC Digitalis, UC Pombalina e UC Impactum, pressupõem a aceitação plena e sem reservas dos Termos e Condições de Uso destas Bibliotecas Digitais, disponíveis em https://digitalis.uc.pt/pt-pt/termos.

Conforme exposto nos referidos Termos e Condições de Uso, o descarregamento de títulos de acesso restrito requer uma licença válida de autorização devendo o utilizador aceder ao(s) documento(s) a partir de um endereço de IP da instituição detentora da supramencionada licença.

Ao utilizador é apenas permitido o descarregamento para uso pessoal, pelo que o emprego do(s) título(s) descarregado(s) para outro fim, designadamente comercial, carece de autorização do respetivo autor ou editor da obra.

Na medida em que todas as obras da UC Digitalis se encontram protegidas pelo Código do Direito de Autor e Direitos Conexos e demais legislação aplicável, toda a cópia, parcial ou total, deste documento, nos casos em que é legalmente admitida, deverá conter ou fazer-se acompanhar por este aviso.

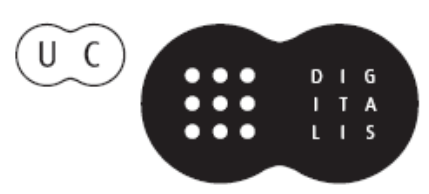




\section{BRAILA ONDE O DANÚBIO VEM À CIDADE}

NICOLAE LASCU (Coordenador)

ANDREEA MIRELA CHINA 


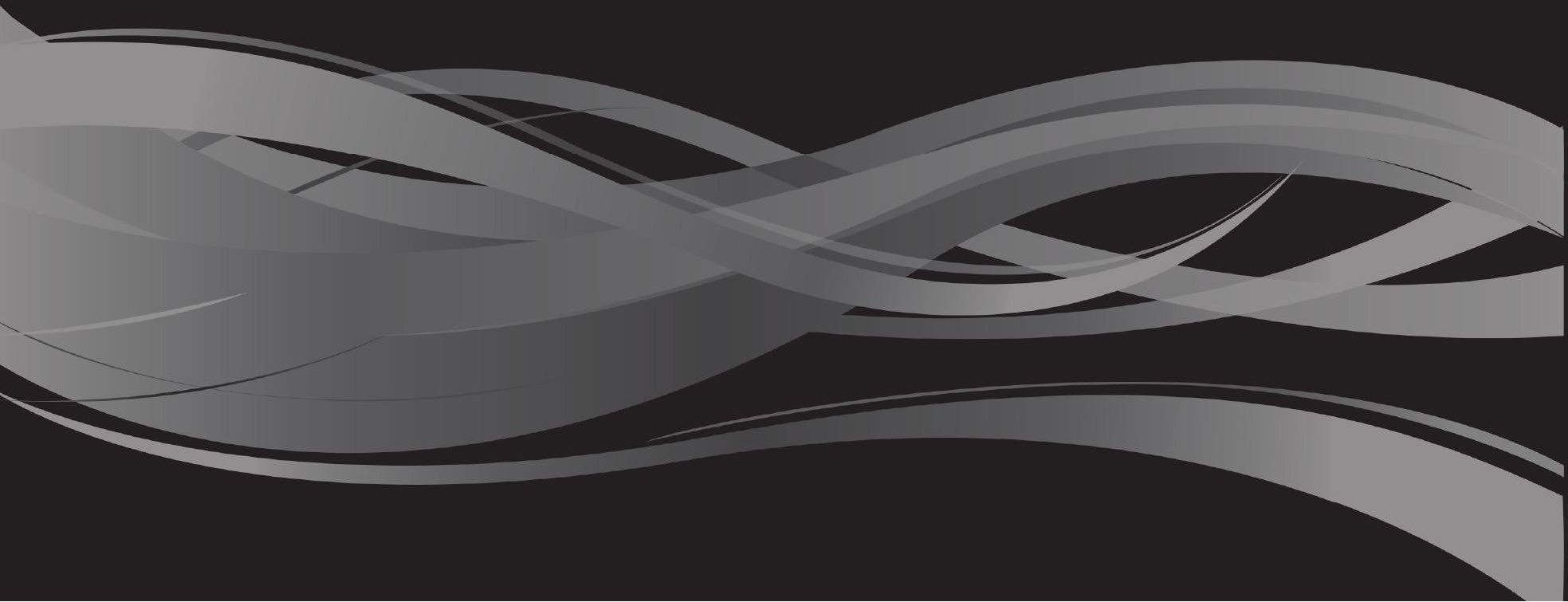




\section{O DANÚBIO E A FRENTE RIBEIRINHA DE BRAILA}

À luz das atuais tendências, que conferem ao desenvolvimento sustentável uma importância crescente, resulta claro que Braila, cidade pós-industrial com um débil desenvolvimento económico, poderá reativar o seu antigo estatuto de porto danubiano se se propuser explorar o rio enquanto via de transporte limpa e eficiente, reconvertendo e reinventando, do mesmo passo, a utilização do seu património industrial abandonado.

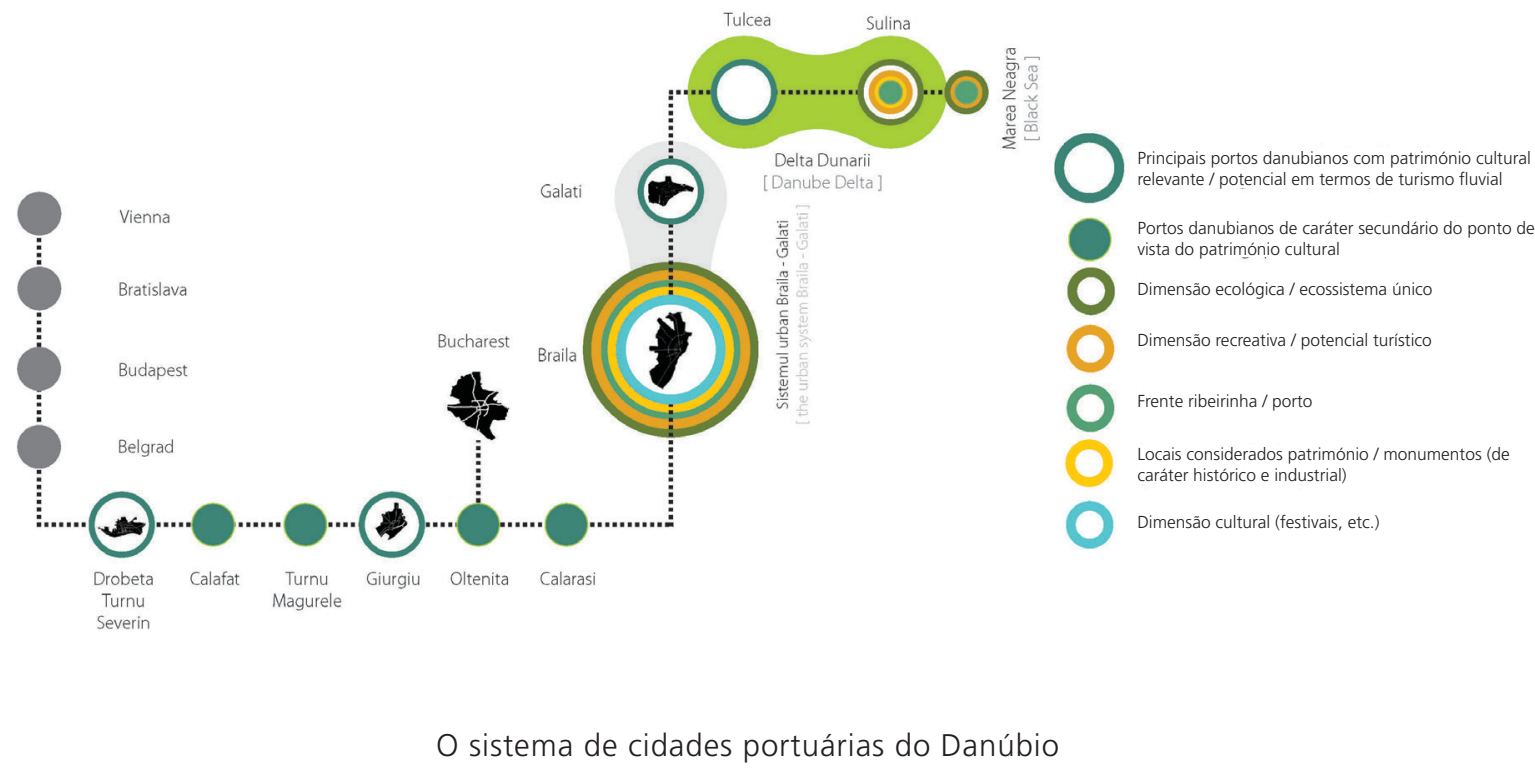

Parte integrante de um sistema de cidades portuárias situadas ao longo do Danúbio, e em posição de vir a assumir um lugar significativo a nível europeu, Braila - a exemplo das restantes cidades ribeirinhas - figura na Estratégia da União Europeia para a Região do Danúbio. A Comissão Europeia deu prioridade a 4 grandes eixos, que constituem o conteúdo central para a estratégia do Danúbio:

- Ligação da Região do Danúbio: incluindo a mobilidade, a energia sustentável, a cultura e o turismo;

- Proteção do Ambiente na Região do Danúbio: incluindo a qualidade da água, a prevenção do risco, a biodiversidade e a paisagem;

- Fomento da Prosperidade na Região do Danúbio: incluindo o conhecimento, a educação, e ainda o investimento nas pessoas e nas competências;

- Reforço da Região do Danúbio: capacidade institucional e cooperação, proteção e segurança.

Com estas iniciativas propõe-se a União Europeia desenvolver e alargar a navegação nos rios interiores, tornando assim possível, graças à Estratégia da UE para a Região do Danúbio, atraiar empresas de turismo de maneira a maximizar o potencial turístico e a fortalecer as ligações culturais. 
A posição dominante que Braila ocupa na parte romena do Danúbio tem reflexo no potencial turístico da cidade, por sua vez decorrente do património edificado, dos sítios protegidos (património tangível e intangível, extremamente rico e variado), da dimensão cultural (festivais de música como o Concurso Internacional de Canto Hariclea Darclee e outros eventos) ou da dimensão ambiental (veja-se a biodiversidade e a riqueza ecológica da llha Pequena de Braila - classificada na Rede NATURA 2000 ou da Ilha Grande de Braila, elementos que, no seu conjunto, constituem uma unidade de paisagem).

No plano do território, as vizinhas cidades portuárias de Braila e Galati começam a dar forma a um único sistema urbano, especialmente do ponto de vista administrativo. Mas uma relação ainda mais fácil de explorar será a que a cidade mantém com a Ilha Grande de Braila, que poderá funcionar caso nela seja introduzida uma vertente recreativa sob a forma de extensão funcional da cidade. Sendo este um espaço pouco utilizado, devido principalmente à falta de um acesso direto entre os dois territórios - a cidade e a ilha -, a expansão de certas áreas de lazer através da transferência de algumas atividades para a zona fronteira à cidade (como a praia, no verão, infraestruturas para a pesca no inverno, etc.) poderá revelar-se altamente eficaz.

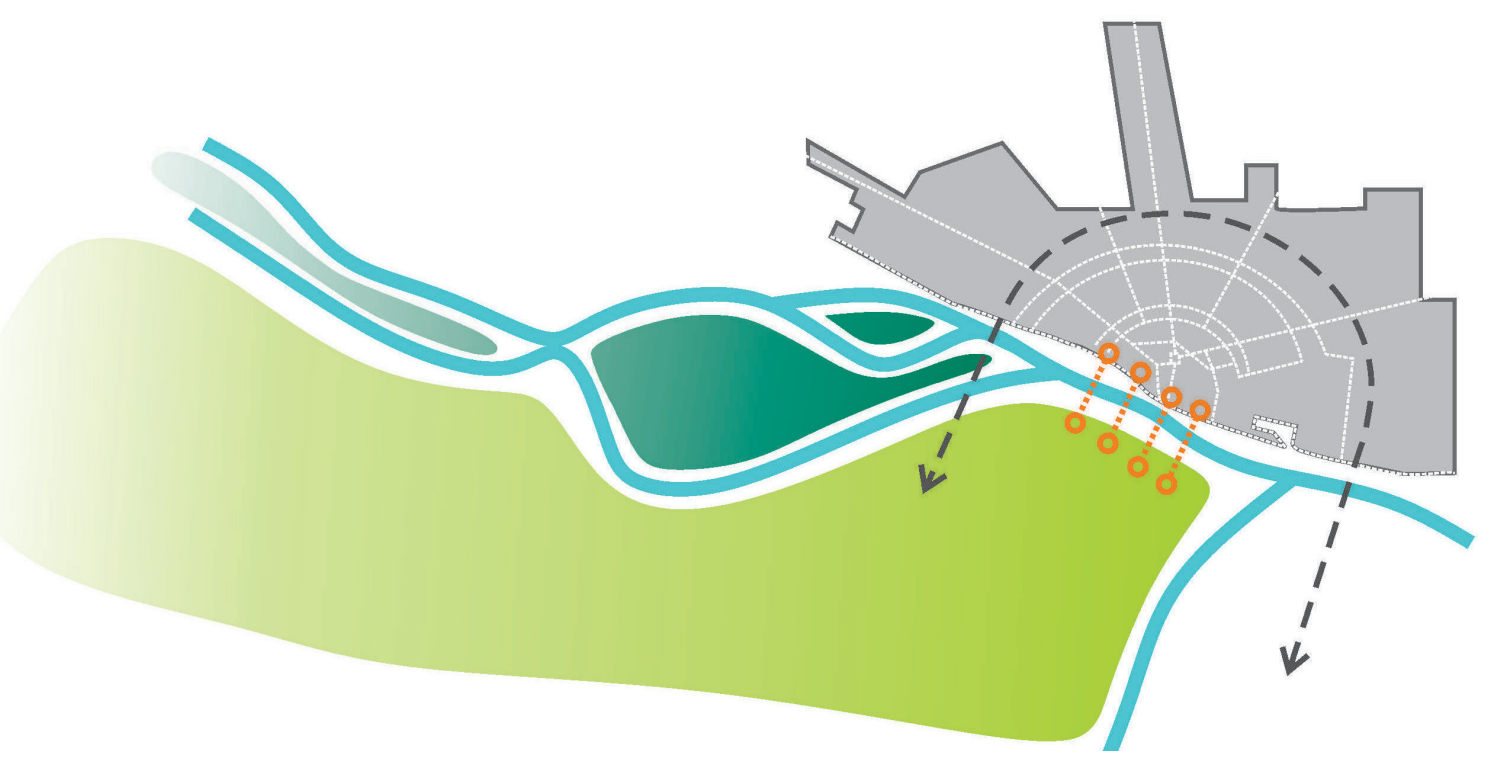

Esquema da relação de Braila com o território envolvente

Nenhuma destas propostas de estabelecimento de relações territoriais com Braila poderia ser levada a cabo sem ter em conta as formas de revitalizar o papel da frente ribeirinha na relação com a cidade. Estamos perante uma relação ambivalente, em que a água desempenha um papel funcional no nascimento e crescimento da cidade, e que não só não pode ser negada como só pode ser expressa "voltando" a cidade e respetivas atividades para o rio e integrando o rio, por sua vez, na vida e na economia da cidade.

Para a prossecução deste objetivo, as áreas de intervenção em que o projeto se centrou foram, assim, associadas diretamente à frente ribeirinha e à relação potencial entre o rio e o centro histórico. 
A área de intervenção definida pelo novo centro administrativo (situado na Avenida da Independência) e pela zona do porto (Rua Vadul Rizeriei) constitui a principal área de contacto entre o rio e a cidade, sendo aí que reside o maior potencial com vista a uma requalificação (já que possui tanto áreas não edificadas como um rico património industrial - o qual, apesar de se encontrar em avançado estado de ruína, é passível de restauro e de reutilização).

O projeto optou por dividir as áreas de intervenção de acordo com o seu perfil específico, de maneira a restaurar os laços entre as diferentes zonas da cidade e as atividades relacionadas com a água. Considerou-se que uma abordagem deste tipo poderá traduzir-se também em estratégias de longo prazo. Assim, a proposta centra-se na criação de conexões diretas entre as áreas residenciais (os principais pontos de concentração humana) e a frente ribeirinha. A proposta tem um duplo propósito: fazer a ligação norte-sul, ao longo do rio, e estabelecer conexões na direção este-oeste. Quanto ao eixo este-oeste, o problema está nos obstáculos impostos pela própria topografia (isto é, no facto de a parte mais nova da cidade se ter desenvolvido no patamar mais elevado, por oposição ao núcleo histórico e ao porto, que se foram desenvolvendo no vale do Danúbio).

Em relação à frente ribeirinha (a área de intervenção), a equipa identificou três subzonas que como tal foram definidas e sobre as quais nos debruçaremos de seguida: a Promenada, área de passeio entre o novo centro administrativo (o espaço público frente à Câmara Municipal) e a antiga Gare Fluvial; a praça da Gare Fluvial; e o Jardim Público mais a área abaixo deste espaço - dentro dos limites da zona liberta relacionada com as atividades portuárias, área que inclui também a Fábrica Lichiardopulos. Uma quarta área será a do espaço relacionado com o porto, mas considerações de ordem económica justificam que não seja aqui tratada.

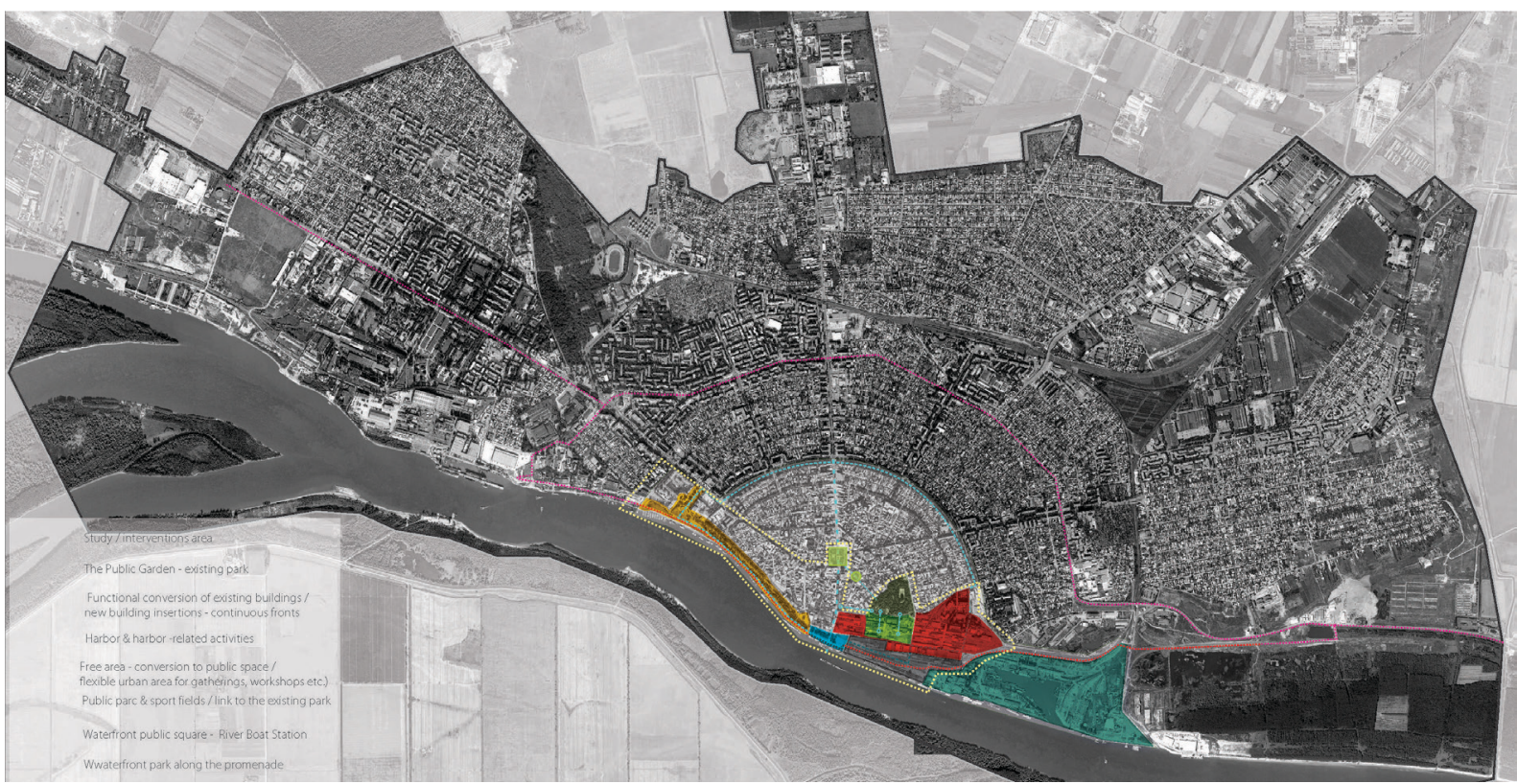

As principais áreas de intervenção do projeto 
1titin

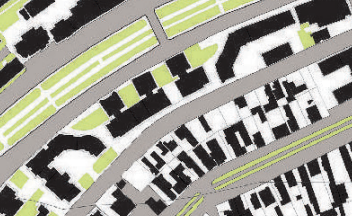

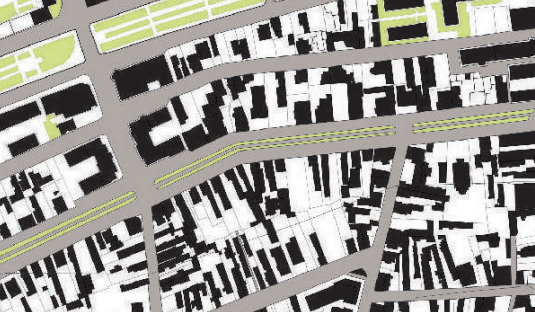

a.

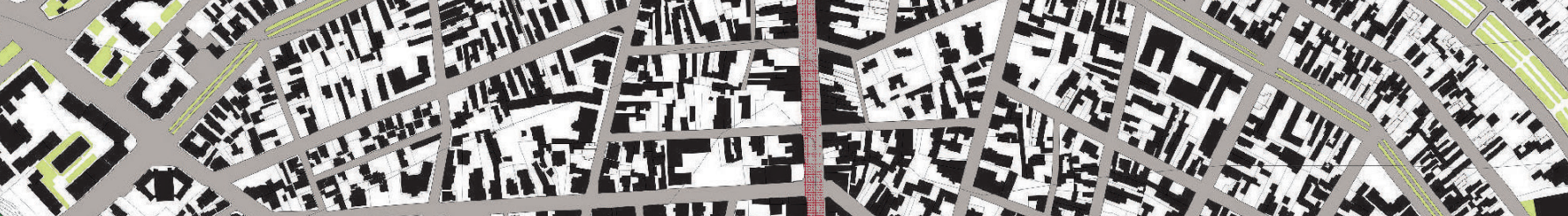

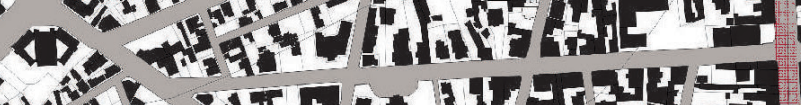

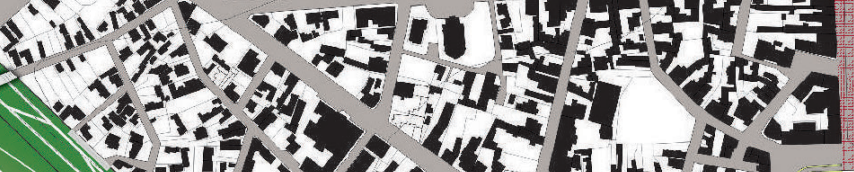

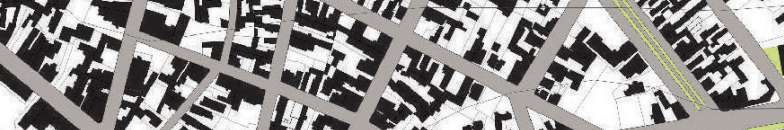

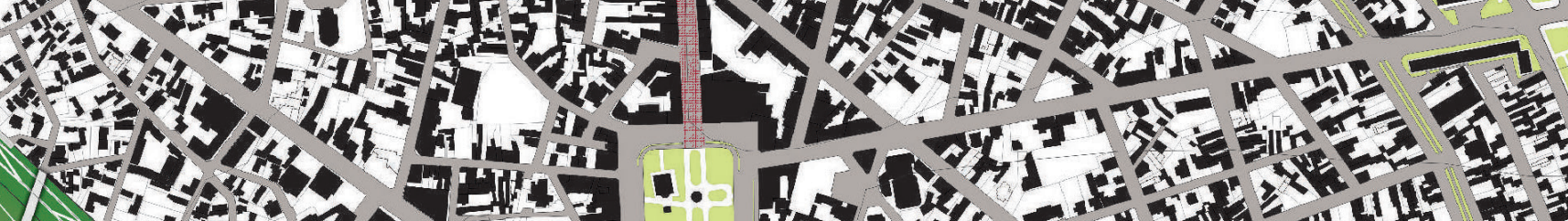

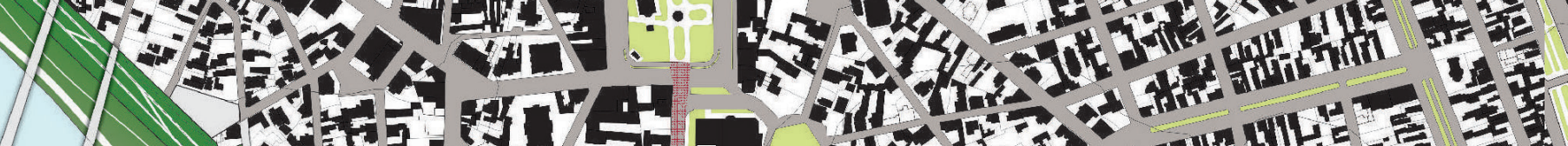
4 (1)

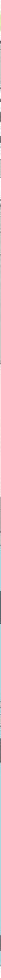




\section{A Promenada - primeira área de intervenção / workshop}

Na sequência da análise e do diagnóstico levados a cabo naquilo que foi a abordagem lógica do projeto, a primeira área tratada em pormenor foi a sugerida para o workshop realizado em Lille, ou seja, a área definida pelo novo centro administrativo da cidade (a Avenida da Independência) e pela Gare Fluvial (Rua do Imperador Trajano). É a zona de passeio existente ao longo da margem. A razão para a escolha desta área foi que, presentemente, ela é a principal zona de ligação entre a cidade e o rio, funcionando como espaço quase público.

O desafio neste caso consistiu, antes de mais, em ultrapassar os obstáculos apresentados pela topografia e em desenvolver novas ligações entre o centro histórico e a frente ribeirinha. Outro aspeto a necessitar atenção foi o do próprio traçado do espaço linear de passeio, de maneira a realçar-Ihe a função de elo urbano, para que se venha a tornar um ponto central de interesse e vá, ao mesmo tempo, ao encontro de todas as necessidades dos seus diversos utilizadores (a cidade dispõe de um número limitado de áreas capazes de corresponder à procura de espaços públicos de qualidade).
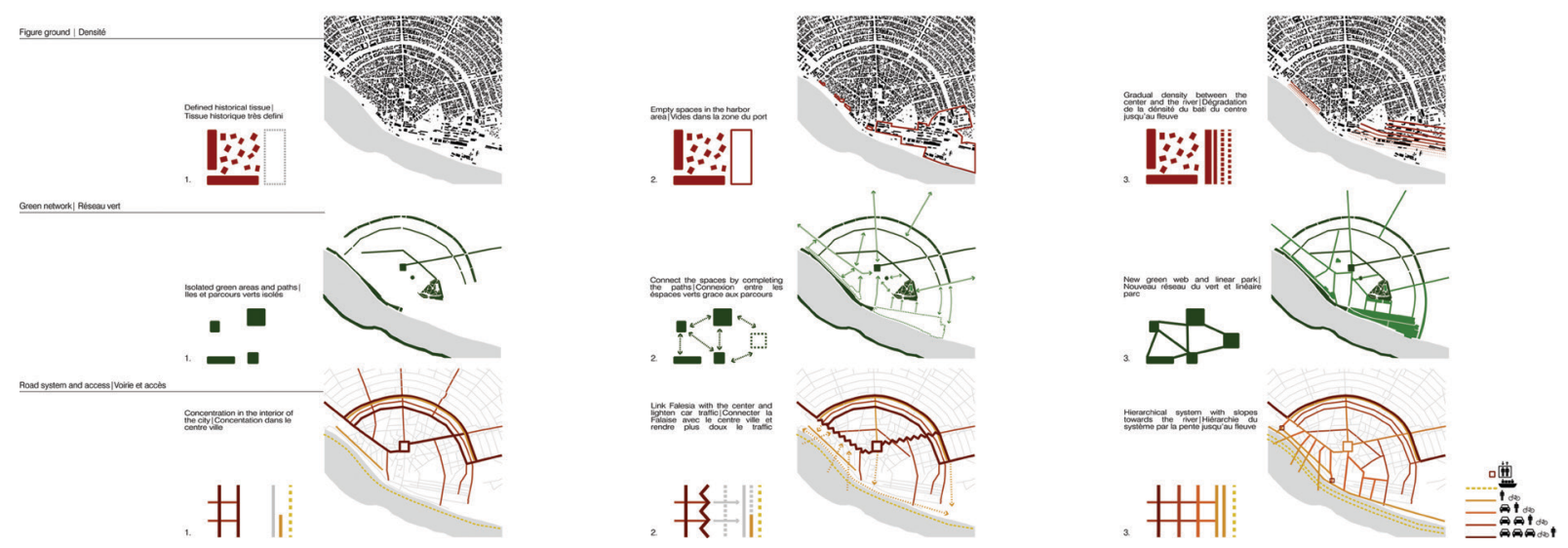

Workshop - A análise

A lógica da solução encontrada assentou na análise prévia, pela equipa, das principais características da cidade e respetiva estrutura e, consequentemente, da área em estudo. Atendeu-se, portanto, à tipologia dos espaços existentes, cuidando de manter a identidade local e, acima de tudo, explorando o topografia do terreno. Aproveitou-se, assim, o desnível - que ao mesmo tempo funciona como barreira entre as duas áreas de maior importância (o centro histórico e a frente ribeirinha) -, desta forma transformado em elemento de ligação. 


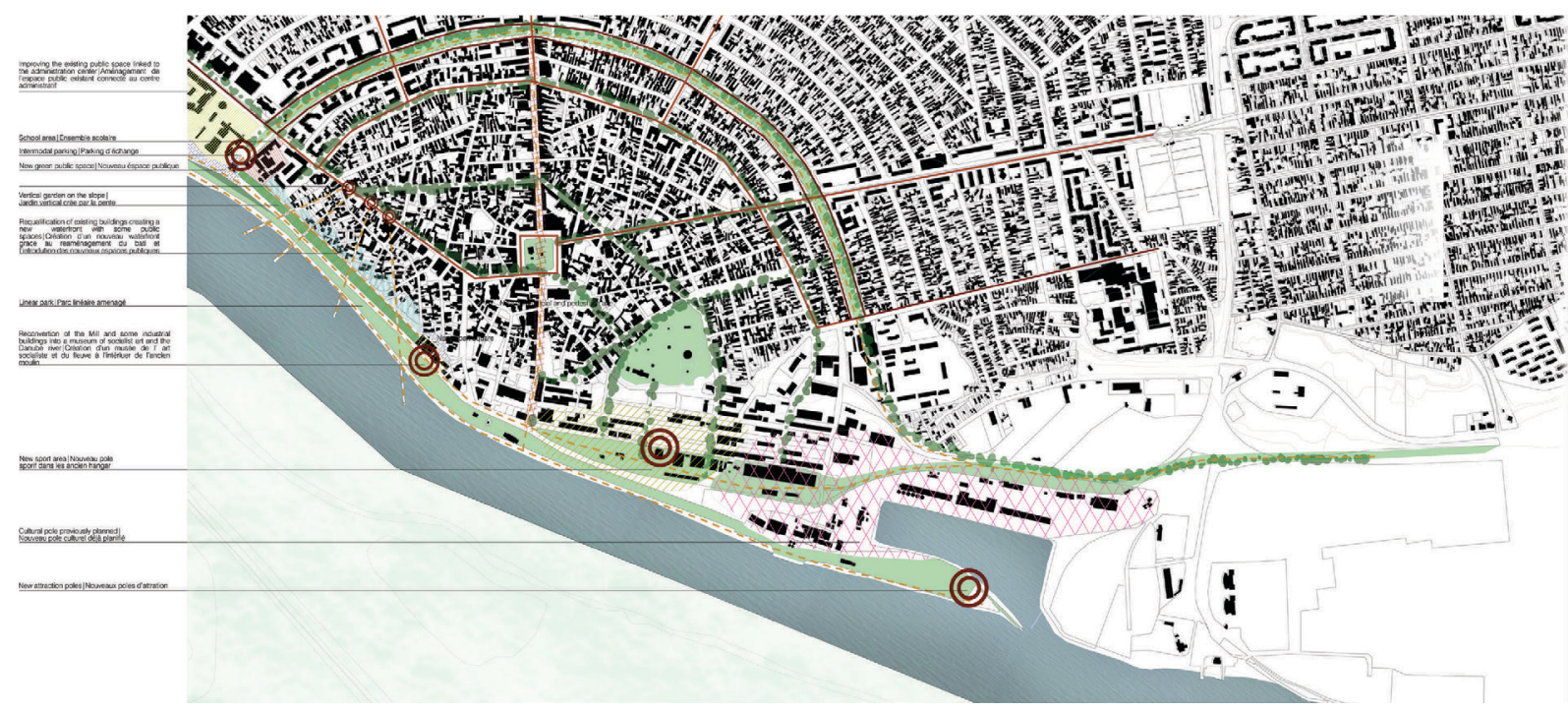

Workshop - A proposta

O principal objetivo do projeto consistiu em reforçar a relação entre a cidade e o Danúbio, conferindo destaque - ou dando origem - a espaços públicos sem deixar de preservar a integridade e a singularidade da estrutura urbana. A proposta centrou-se nos seguintes tipos de intervenção: reabilitação do património arquitetónico e urbano, ligação entre os principais polos de atração e locais de referência, preservação e alargamento da estrutura urbana característica do centro da cidade, e realce da traça desta área.

A acessibilidade foi um dos principais aspetos sobre os quais a equipa fez incidir o seu estudo, por achar que um dos principais problemas em presença era o de conseguir uma melhor ligação entre a cidade e o rio. Este aspeto foi solucionado de diversos modos. Em primeiro lugar, criando vias transversais capazes de direcionar o tecido urbano para a água e, simultaneamente, transpor o desnível abrupto. Em segundo lugar, criando pontos de interesse com vista à utilização do espaço, conferindo-Ihe um uso de interesse público e devolvendo-o, assim, à cidade por forma a que volte a fazer parte do seu sistema. 


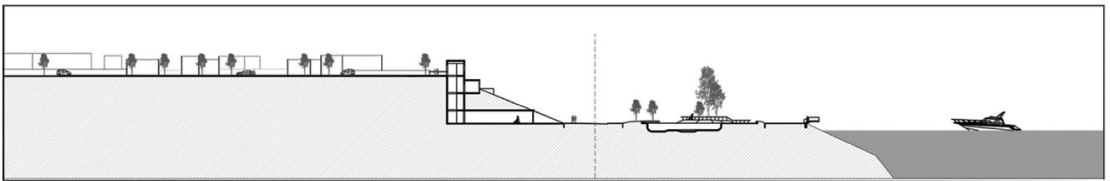

Section trought access for disabled people to the river I Coupe transversale de lacces au flevve pour les personnes handicapés
$1: 500$
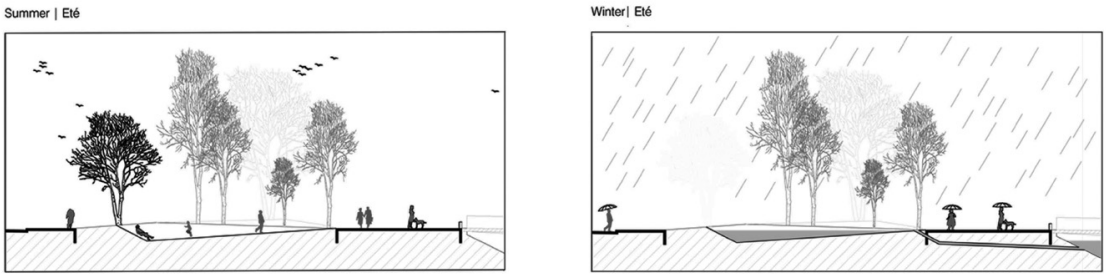

Focus on the game of water levels in the green spacel Zoom sur les jeux d'eau le long de la promenade
1.200
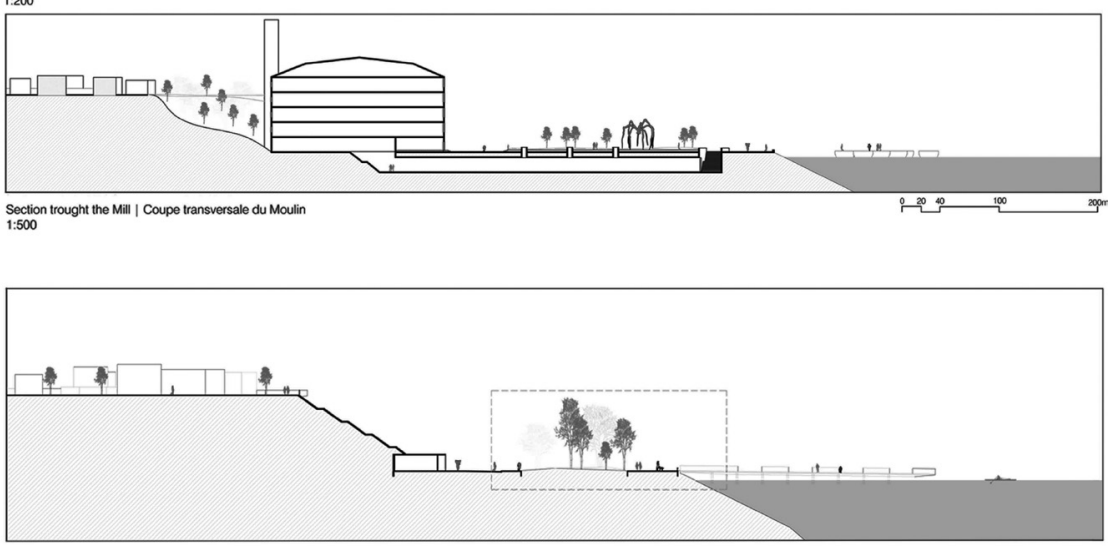

Section trought one of the main access to the river | Coupe transversale de l'acces principal au fleuve
$1: 500$

Workshop - Cortes transversais constantes da proposta

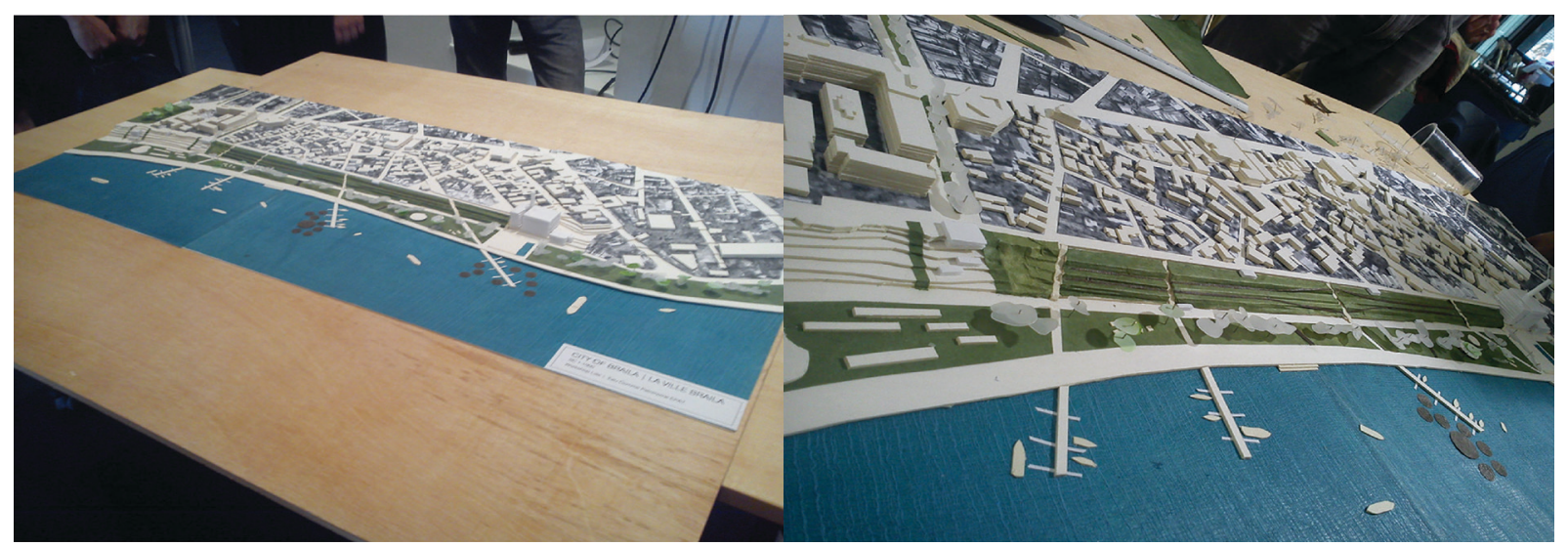

Workshop - O modelo 


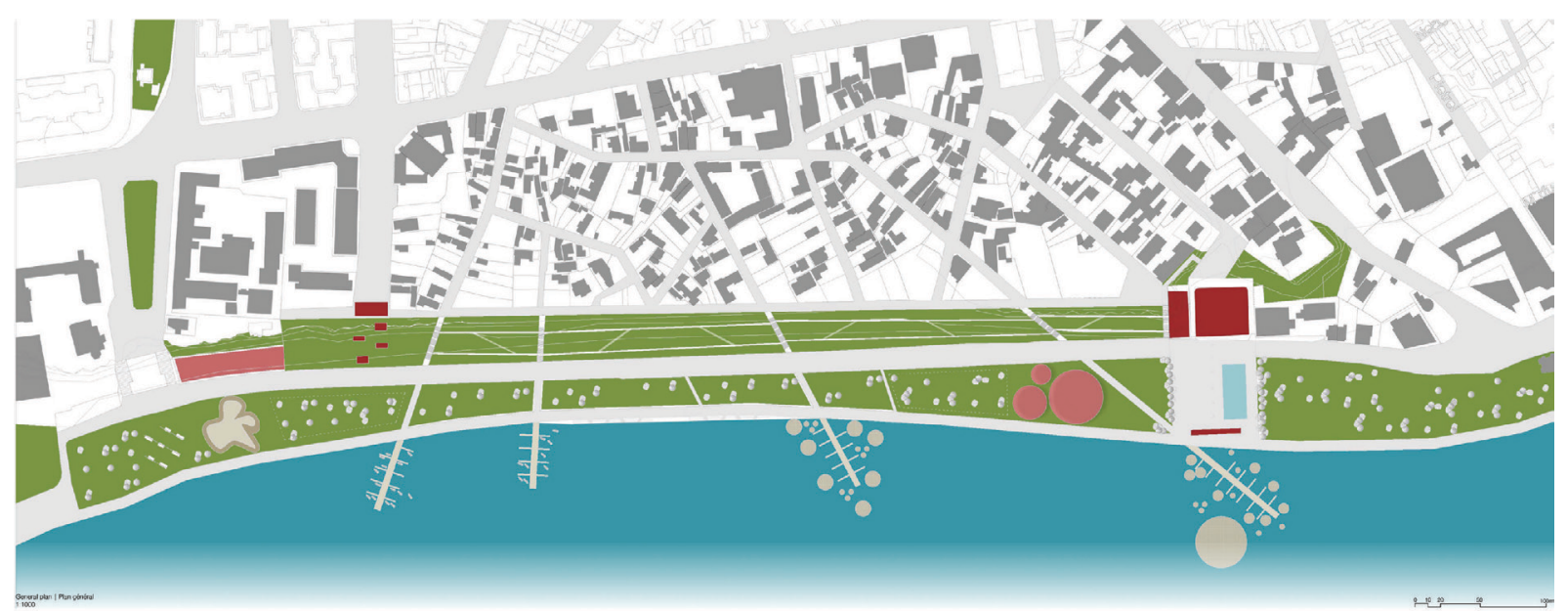

Workshop - A proposta

Uma vez solucionado o problema da acessibilidade, a equipa debruçou-se sobre a questão do desenvolvimento económico, trazendo para a cidade funções rentáveis e reutilizando ou reconvertendo o património edificado existente. A reconversão de edifícios considerados património constitui um passo essencial para a revitalização da economia e de toda a área urbana, visto o património ser um dos elementos-chave para pôr em relação as diferentes áreas com as suas também diferentes características. Além disso, na reconversão do património poderão estar os alicerces de estratégias de revitalização de longo prazo eventualmente aplicáves a toda a cidade. No que diz concretamente respeito ao património urbano e industrial, foi dada especial atenção a um espaço de referência local, a Moagem Violatos, edifício industrial de valor histórico, arquitetónico e urbanístico, hoje em adiantado estado de ruína. A proposta visa transformá-lo em museu, sublinhando assim o seu papel enquanto elemento de ligação urbana (através de pontos de atravessamento e passagens do socalco superior para o inferior). A equipa refletiu sobre a utilização deste espaço como museu, um lugar destinado à recolha, pesquisa, restauro, preservação e exibição de todas as formas de arte entre os anos de 1950 e 1990, um lugar, enfim, destinado a sensibilizar as pessoas para a própria história da cidade de Braila. Por sobre o padrão urbano convencional a equipa propõe, ademais, uma "alteração" do terreno plano, criando pequenos lagos que podem ser preenchidos com água através de alagamento controlado, de maneira a sublinhar e evocar o incomensurável valor ecológico do Danúbio.

\section{Uma segunda área de intervenção - pós-workshop}

Ao formular a resposta para as demais áreas de intervenção tivemos em atenção as intervenções propostas no âmbito do workshop. Assim, se, em relação à zona linear de passeio, a proposta aponta 
para o traçado de um espaço público ao longo da frente ribeirinha e para o prolongamento, como consequência natural, do tecido urbano histórico em direção à água, em relação às demais áreas de intervenção a proposta irá manter a mesma lógica: ou seja, a criação de ligações tanto na direção este-oste como na direção norte-sul. Levámos também em conta as intervenções realizadas em monumentos específicos de interesse local, que podem desempenhar funções diversas na articulação dos espaços. O objetivo principal desta fase é devolver à água a sua função original: a de moldar a forma urbana e de ser a principal força motriz do desenvolvimento económico. Para esta fase, por conseguinte, o projeto centrou-se nas áreas delimitadas pela Gare Fluvial / Rua do Imperador Trajano e na zona do porto (ainda operacional).

1. O prolongamento, em direção ao rio e ao longo do principal eixo histórico - a Rua do Imperador Trajano -, da via pedonal foi consequência da ligação ao rio do principal centro de comércio, localizado no primeiro anel da cidade. Isto foi realizado por meio da "duplicação" da Praça de Trajano até à frente ribeirinha e da criação de um novo espaço público em torno da Gare Fluvial. A nova praça pública tem uma dupla finalidade: irá funcionar como ponto de inflexão para uma via pedonal apontada ao rio, na direção este-oeste, e como términus do parque linear situado ao longo da margem (direção norte-sul). A nova praça funciona como ponto de passagem entre dois tipos de espaço, diferentes entre si dos pontos de vista arquitetónico e funcional. Propomo-nos, ainda, restituir à Gare Fluvial a sua principal função, que é servir os passageiros das embarccações que navegam no Danúbio.

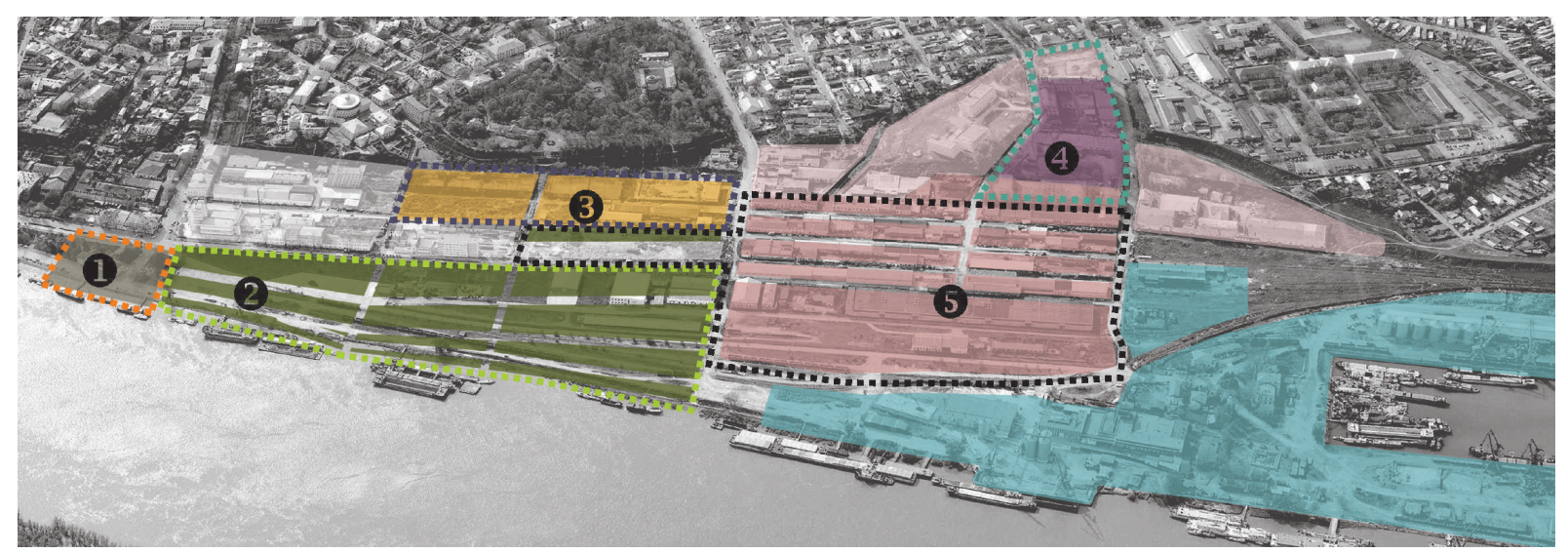

Pós-Workshop - Áreas de intervenção

2. A zona liberta do porto fica simbolicamente "livre de edifícos", de maneira a proporcionar à cidade um espaço flexível, a utilizar de diferentes modos consoante as necessidades de cada momento. O novo espaço assim liberto pode ser ativado por via da extensão das atividades eventualmente a terem lugar nos pavilhões lineares de armazenamento, como feiras periódicas ou outros eventos de 
caráter público. Em relação ao traçado geral, a equipa decidiu que, para restaurar a imagem original, a criação de um sistema mínimo de veredas (a lembrar o tecido urbano original da zona das docas) seria a melhor forma de assegurar a continuidade do aspeto predominantemente linear desta área. O traçado do resto desta zona reveste-se de um caráter subsidiário. É ainda propósito da equipa recuperar a antiga via férrea, hoje abandonada, e que será utilizada como "passagem"/evocação do passado, através de um conjunto de inscrições a assinalar os acontecimentos importantes da longa história de Braila.
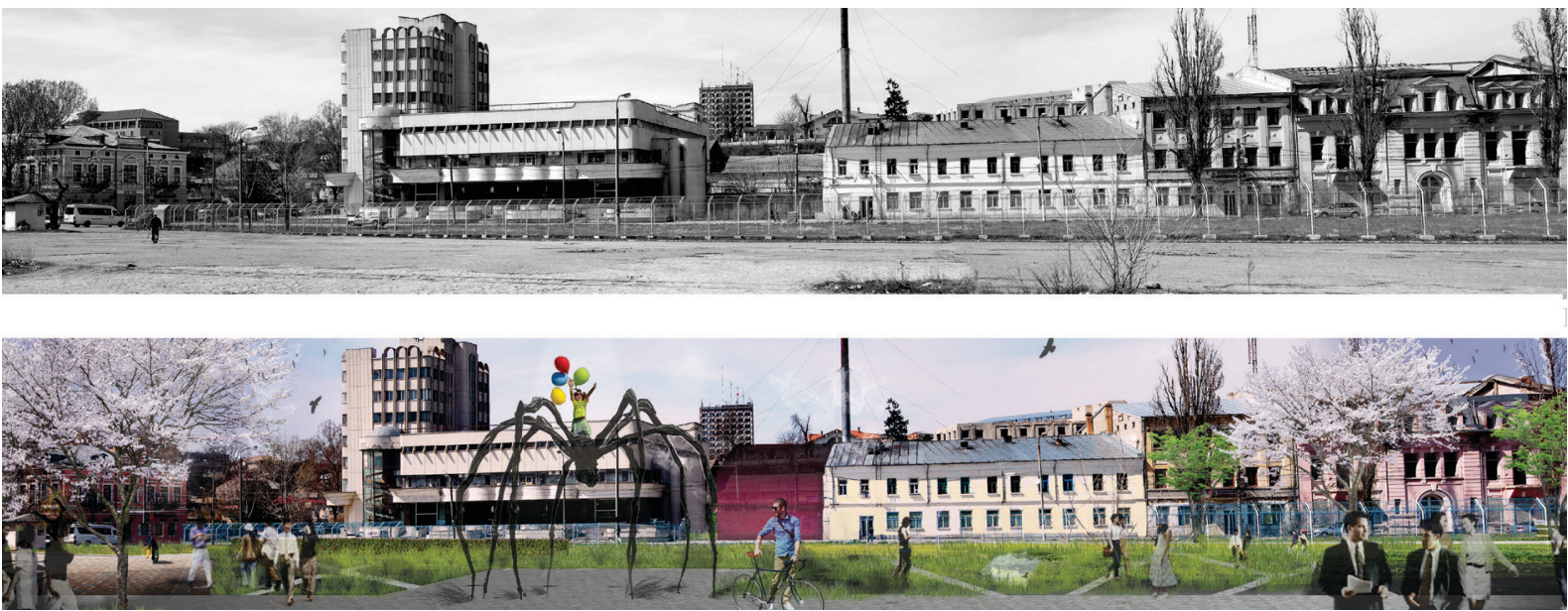

Pós-Workshop - A proposta de uma "zona livre"

3. Um outro marco citadino, o Jardim Público, pode ser considerado o mais "genuíno" ponto de ligação entre a frente ribeirinha e o centro histórico. Ou seja: Tomando por base as cartas antigas de Braila, onde o único ponto de ligação era o jardim, o alargamento do espaço verde desde o socalco superior da cidade até ao socalco inferior constitui uma solução orgânica. Esta função vem acrescentar-se às infraestruturas desportivas existentes. É usada vegetação para criar uma barreira entre a parte de desporto e os pavilhões, mas também para proporcionar a necessária dose de privacidade às zonas residenciais circundantes. Respeitando a topografia natural do terreno, limitámos as intervenções e mantivemos a área de ligação (um declive bastante acentuado) desimpedida de vegetação alta, de maneira a viabilizar o potencial de "miradouro" do terreno mais elevado.

4. Em relação ao património industrial construído, a Moagem Lichiardopulos é, juntamente com a Moagem Violatos, um dos edifícios mais representativos e interessantes. Propomos, por isso, a reconversão do edifício, que poderá de futuro levar a uma revitalização de toda a área circundante. Partindo de uma base espacial flexível, com uma fachada simples e de elementos repetitivos, a solução a adotar deverá passar por uma mescla das seguintes funções: hotel, centro de negócios, auditório para congressos e atividades correlatas. Estas hipóteses surgem como funções de apoio e complemento relativamente ao potencial turístico da cidade e do rio. 


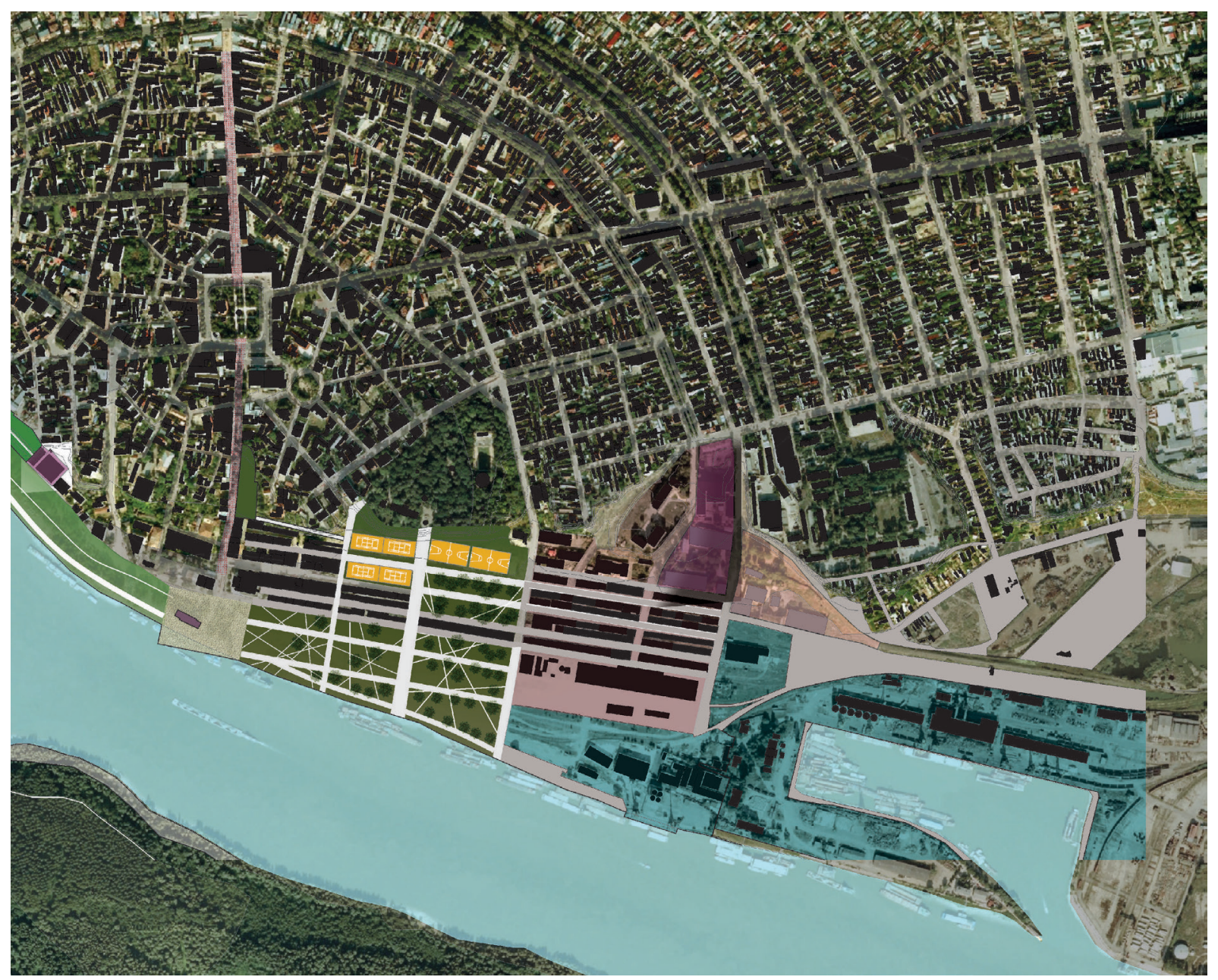

Pós-Workshop - O projeto 

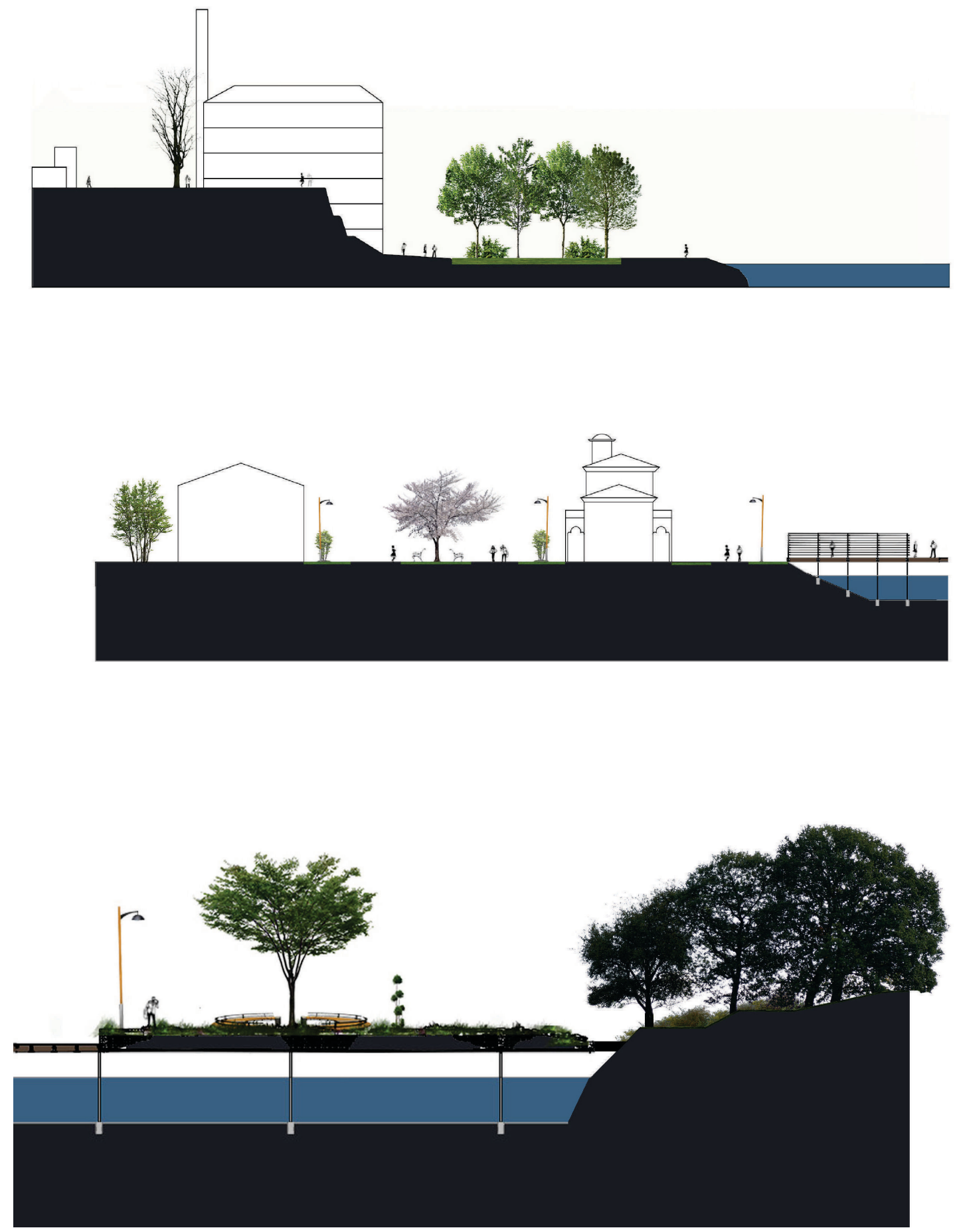

Pós-Workshop - Proposta de cortes transversais para o Jardim Público, Praça da Gare Fluvial, e Ilha Grande de Braila 

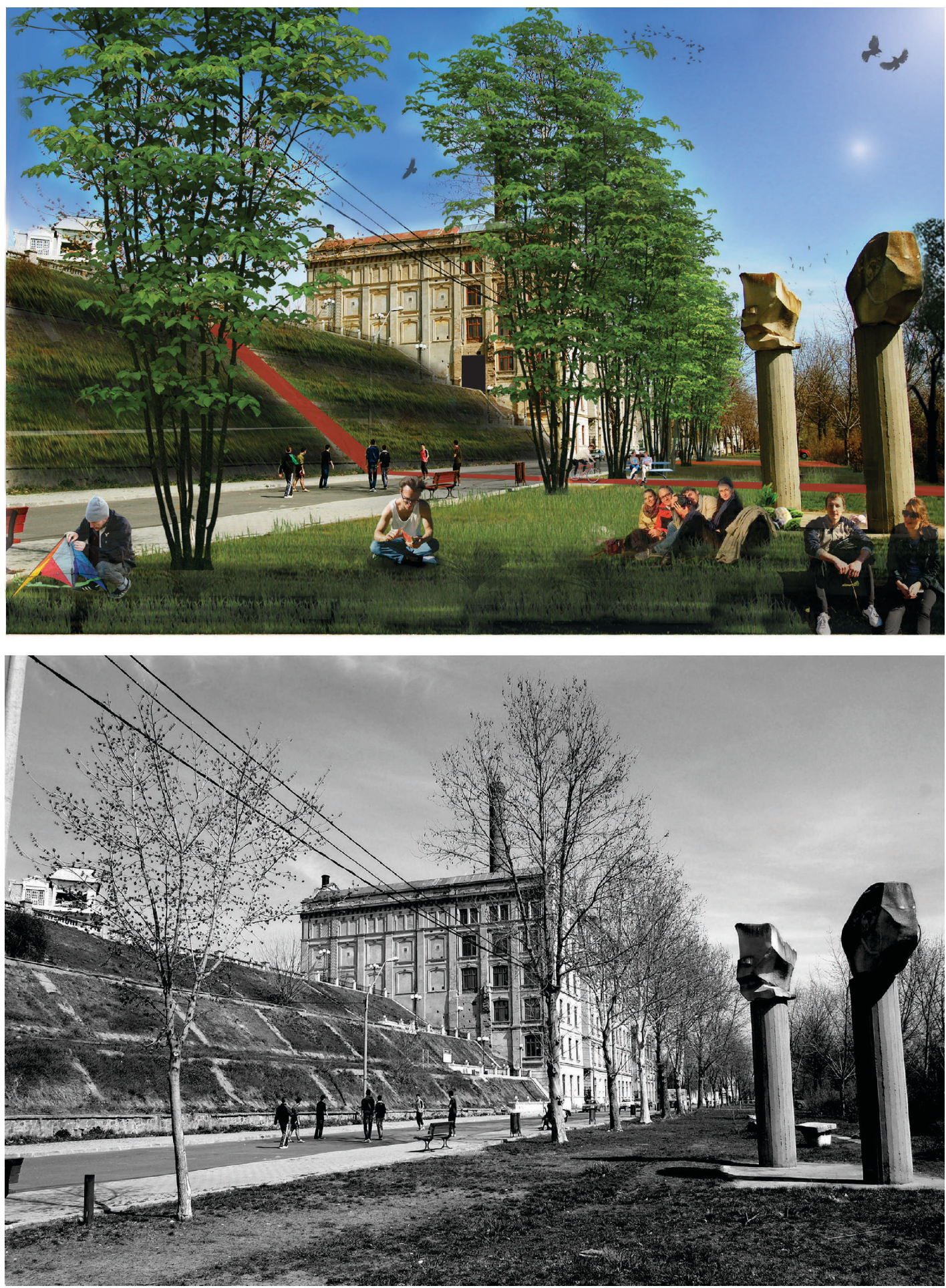

Pós-Workshop - Proposta para a Moagem Violatos 

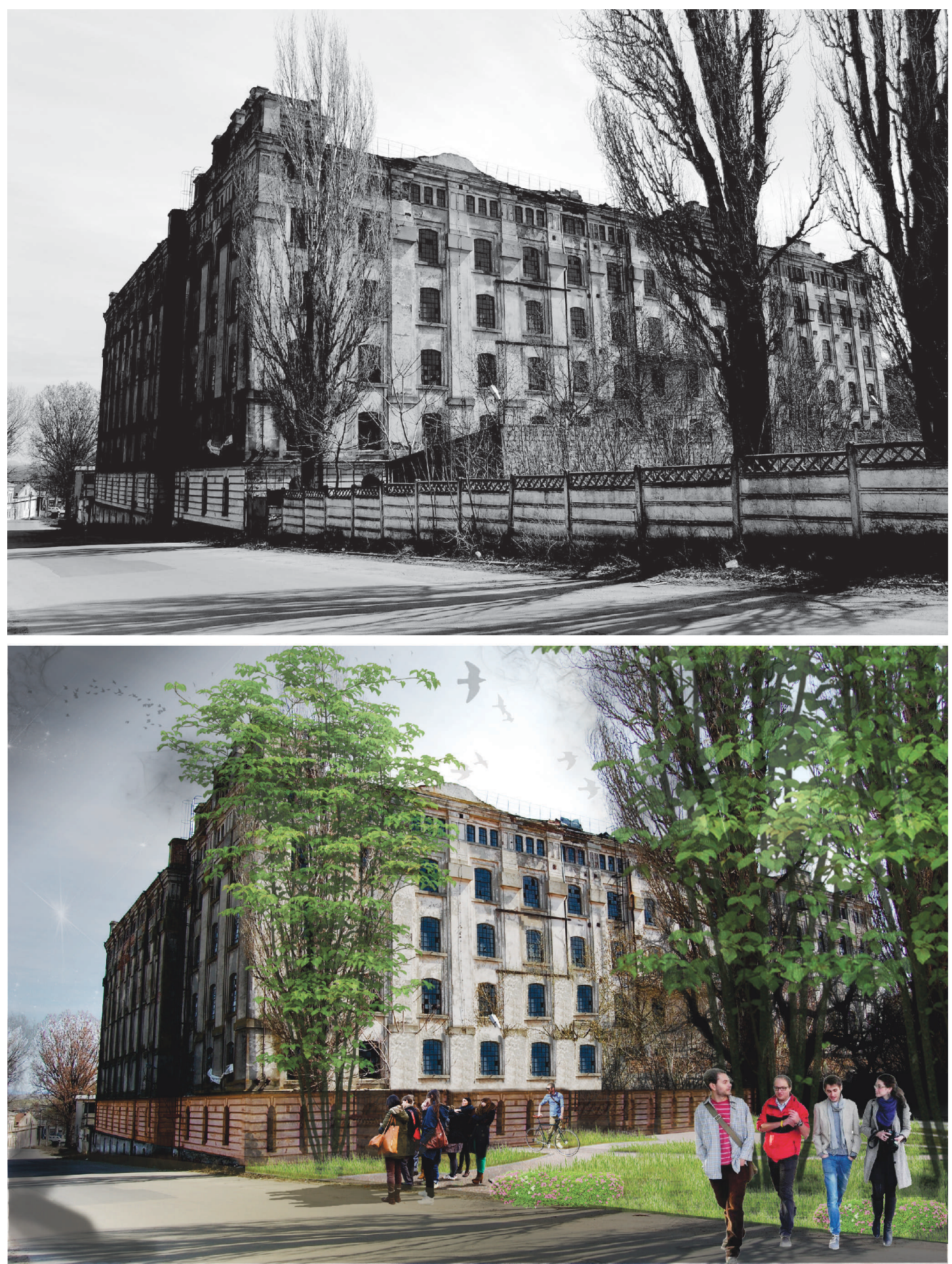

Pós-Workshop - Proposta para a Moagem Lichiardopulos 


\section{Bibliografia}

ANTIPA, GRIGore (1921), DUN Ă REA ŞI PROBLEMELE EI ŞTIINŢIIICE, ECONOMICE ŞI POLITICE. BUCUREŞTI: LIBRĂRILE CARTEA ROMÂNEASCĂ. Braila modernă. Cărţı poştale ilustrate, colecţia Valeriu Avramescu (2006), Muzeul Brăllei \& Editura Istros.

Drăgan, Costel (2012), Scenaril de dezvoltare a sistemului urban Braila - Galati. URbanismul, nR. 12-13, p. 76-78.

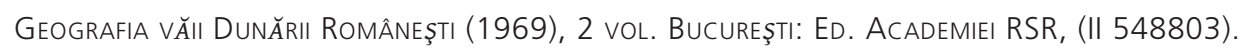

Iosipescu, Raluca e losipescu, Sergiu (2010), Oraşe port la Dunărea de jos şı Pontul nord-Vestic. Urbanismul, nr. 5-6, P. $41-45$.

Lascu, Nicolae (1994), Epoca regulamentară şı urbanismul - cîteva observaţı Generale. Historia urbana, tom II, nR. 2, P. 119-130.

Lascu, Nicolae (2010), Sistemul teritorial Dunăre - Marea Neagră în epoca modernă. URbanismul, NR. 5-6, P. 38-40. Oancea, D. I. (1973), Gruparea urbană Galatı - Bralla. Bucureşti: ed. Academiel RSR.

SÂrbu, Cătălin (2012), Un sistem urban aparte: Bralla - Galati. Urbanismul, nR. 12-13, P. 78-89.

Solomon, Marica (2001), Premise şı evoluţu ale evoluţiel coceptului peisaj cultural, in Peisaj cultural şı dezvoltare. BuCUREŞTI: ED. Universitară ION Mincu, P. 15-32.

Solomon, Marica (2010), Dobrogea ca unitate de peisaj - O abordare CUlturală A teritoriului. URbanismul, NR. 5-6, P. $32-37$.

Stoica, Maria (2009), Braila. Memoria oraşului. Imaginea unui oraş românesc din secolul al XiX-lea. Bralla: Ed. Istros.

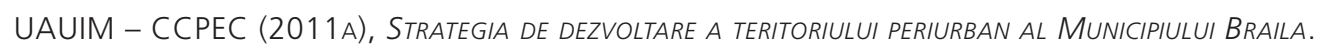

UAUIM - CCPEC (2011B), Atualizare Plan URbanistic General BraILa.

Urban Proiect (2008), Planul Urbanistic Zonal - Centrul istoric al Municipiului Bralla. 